\title{
5. Scars of early job insecurity across Europe: insights from a multi- country employer study
}

\author{
Christian Imdorf, Lulu P. Shi, Stefan Sacchi, \\ Robin Samuel, Christer Hyggen, \\ Rumiana Stoilova, Gabriela Yordanova, \\ Pepka Boyadjieva, Petya Ilieva-Trichkova, \\ Dimitris Parsanoglou and Aggeliki Yfanti
}

\section{INTRODUCTION}

Early unemployment is associated with lower income, poor work quality and diminished chances of future employment. These issues have gained new relevance since the Great Recession (Dietrich, 2012; Scarpetta et al., 2010), which affected young jobseekers across Europe. The persisting consequences of employment instability and unemployment are studied and are known in the literature as scarring effects, but researchers have paid little attention to date as to how the scarring effects of early unemployment on hiring prospects differ across countries. In this chapter we study how unemployment spells and other signals of job insecurity in young jobseekers' curriculum vitae (CVs) affect their hiring chances with recruiters in Bulgaria, Greece, Norway and Switzerland.

The chapter contributes to recruitment research in three ways. First, the multi-national research design enables comparative analysis between countries, using the national dimensions of the youth unemployment rate, employment protection legislation (EPL) and type of education system to interpret country differences. Second, the incorporation of a factorial survey experiment in the design allows us to differentiate between two forms of labour market risk - unemployment and work experience in 'bad' (deskilling) jobs. We demonstrate that an exclusive focus on unemployment, as is often adopted in labour market research, is not sufficient for understanding detrimental labour market outcomes. Third, since the sample consists of real recruiters who were hiring for 
current jobs at the time of the study, we obtained a unique international data set with high external validity. The findings indicate that the scarring effects of early unemployment and deskilling jobs vary across countries and education levels and also that frequent job changes (job-hopping) additionally damage future employment chances. Our study has important implications for active labour market policies. The findings suggest that measures seeking to quickly reintegrate young unemployed into the labour market without considering job quality may not be an optimal solution, given that work experience in a bad job can negatively affect recruiters' evaluations.

\section{UNDERSTANDING UNEMPLOYMENT SCARRING}

According to human capital theory unemployment can be understood as missed chances to obtain work-relevant skills and knowledge (Pissarides, 1992). In addition, previously acquired human capital might depreciate during a period of inactivity (Mooi-Reci and Ganzeboom, 2015). There is little consensus as to whether high- or low-skilled workers are better protected against the negative effects of early unemployment. Whereas some scholars argue that high-skilled workers can overcome unemployment easier because they have demonstrated potential productivity (Eriksson and Rooth, 2014), others maintain that unemployment affects low-skilled workers less because they have less human capital that may deteriorate during inactive spells (Bonoli, 2014). Overall, from a human capital perspective we expect employers to prefer applicants without gaps in their careers to applicants with such gaps, all else being equal.

A challenge employers face when hiring is that they cannot directly assess the previous human capital deterioration of job candidates. Moreover, given limited time and resources in the hiring process, it is difficult for them to predict an applicant's productivity. According to signalling theory, recruiters draw on visible cues - signals - such as education, school grades or employment experience to predict an applicant's productivity and suitability for a job (Spence, 1973), thus reducing uncertainty in the hiring process. For young people with little or no job experience, this kind of inferencing is more difficult because there are fewer cues to signal how productive they might be (Bills, 2003; Gangl, 2003b). Gaps in applicants' $\mathrm{CVs}$ can also serve as signals and influence their chances of finding a job. Previous studies have found that employers tend to associate unemployment with unobservable negative qualities such as low productivity, weak motivation, lack of commitment, problematic character qualities or other 
negative traits (Atkinson et al., 1996; Devins and Hogarth, 2005) and that they tend to be careful and reluctant to hire applicants who have previously experienced unemployment. Consequently, some employers may even prefer not to fill a position so as to avoid the risk of disrupting the workplace (Devins and Hogarth, 2005).

We must stress that signals are context dependent and that the way in which employers interpret unemployment depends on various factors. At the micro level, such factors may be characteristics of the job and/or features of the applicants. For example, people may choose to stay voluntarily unemployed if the available jobs do not match their level of qualification or do not satisfy their reservation wage, that is, the proposed pay is below the lowest wage they would be willing to accept (Brown and Taylor, 2009; Ma and Weiss, 1993). In these cases recruiters may not regard having been unemployed as a problematic trait, and employers might perceive unemployment less sceptically in cases of high-skilled applicants because the latter may have higher reservation wages (Pissarides, 2000). At the macro level, factors such as a country's education system or unemployment rate may play important roles. For example, in countries with a high unemployment rate and poor overall labour market conditions, employers may consider unemployment to be a common trait. In such contexts unemployment would be a noisy signal and not very useful for inferring the suitability of applicants (e.g., Lupi and Ordine, 2002). To sum up, from the point of view of signalling theory, employers may use unemployment as a signal to predict an applicant's qualities; and the signalling value of unemployment will depend on contextual factors.

\section{THE ROLE OF NATIONAL CONTEXTS IN UNDERSTANDING UNEMPLOYMENT SCARRING}

The role of national contexts for individuals' employment opportunities and job insecurity risks has been widely discussed. Unemployment rates, labour market regulations - such as EPL (Van der Velden and Wolbers, 2001) - and education systems (Allmendinger and Leibfried, 2003) are important factors influencing individuals' labour market outcomes. However, there is a lack of studies analysing how these macro contexts might determine reintegration into the labour market following experiences of job insecurity. In the following we describe these contextual factors, which are key to understanding how unemployment scarring varies across countries. 


\subsection{Magnitude of Youth Unemployment}

If the overall youth unemployment rate is high, one may assume that an individual's unemployment will have a less negative impact on future job searches. In this situation unemployment is associated to a lesser extent with individual failure (Biewen and Steffes, 2010; Imbens and Lynch, 2006). The recent economic crisis severely hit two of the four countries we studied (Bulgaria and Greece), resulting in high youth unemployment rates especially in Greece. In 2015, 50 per cent of 15-24-year-olds were unemployed in Greece, while 22 per cent of this age group were unemployed in Bulgaria (Eurostat, 2015). Norway and Switzerland, by contrast, exhibited relatively low youth unemployment rates of 10 per cent each during the same period (Eurostat, 2015; Karamessini et al., 2016). Because spells of unemployment are common amongst young people in Greece and Bulgaria, this kind of information may not strongly affect employers' assessments of job candidates in these two countries. In contrast, the same information is likely to attract the attention of employers in Norway and Switzerland because youth unemployment is less common in their national contexts. From the perspective of signalling theory we therefore expect previous unemployment to be a stronger signal in Norway and Switzerland than in Bulgaria and Greece.

\subsection{Employment Protection Legislation (EPL)}

Strict EPL may protect workers against dismissal, but it may also make recruiters more cautious, given that once workers have been hired employers cannot easily fire those who prove to be unsuitable or less productive (Breen, 2005). Such adverse effects are particularly likely for young people with little labour market experience, current or previous unemployment, or low levels of human capital. The reason is that employers will tend to associate more risk with such kinds of job candidate and thus refrain from hiring them.

Many observers have associated strict EPL with higher youth unemployment rates (Breen, 2005; Van der Velden and Wolbers, 2001), but research about the impact of employment protection on unemployment scarring is rare. Recruiters in countries with strict EPL might be more careful about hiring applicants with any sort of early unemployment so as to avoid hiring unsuitable job candidates who would then be difficult to fire. According to the EPL index of the International Labour Organization, Switzerland and Bulgaria had rather weak protection against individual dismissal in 2011 (CH: 0.32; BG: 0.38). In contrast, EPL was stricter in Norway (0.45) and Greece ( 0.46 and 0.51 for blue- and white-collar jobs, respectively; see ILO, 2015). The Labour Freedom Index of the Heritage Foundation (2017) con- 
firms these differences. According to its 2016 data, there was relatively high labour freedom in Switzerland and Bulgaria (72 points for both countries) compared to Greece and Norway, both of which had lower labour freedom scores (50 and 49 points, respectively). Given the stricter EPL in Norway and Greece, we would expect more pronounced unemployment scarring in these two countries compared to Switzerland and Bulgaria.

\subsection{Education System}

The link between a country's education system and the labour market can influence school-to-work transitions and youth employment (Gangl, 2003a; Van der Velden and Wolbers, 2003; Walther, 2006). Countries with strong initial vocational education training (IVET) systems, which provide occupation-specific skills, have comparably smooth transitions (Walther, 2006). Dual-track IVET, where education and training take place in parallel at the workplace and in vocational schools, fosters smooth school-to-work transitions (Allmendinger, 1989; Van der Velden and Wolbers, 2003). The strong involvement of labour market actors in dual-track IVET systems strengthens the alignment of vocational programmes with labour market needs. The resulting vocational certificates serve recruiters as highly informative signals of occupation-specific skills, resulting in a lower share of IVET graduates who are unable to find jobs (Breen, 2005; Sacchi et al., 2016).

With respect to our country cases, the IVET participation rate is lowest in Greece (31.5 per cent). Norway (50.7 per cent) and Bulgaria (53.7 per cent) have IVET rates at intermediate levels, whereas we find the highest IVET rate in Switzerland (65.6 per cent; see Eurostat, 2014; Hora et al., 2016; SERI, 2015). Moreover, dual-track IVET is most prevalent in Switzerland (Buchmann and Sacchi, 1998; Hora et al., 2016) and somewhat less so in Norway (Bäckman et al., 2011; Bjerkeng, 2015). Vocational education and training in Bulgaria and Greece is mainly school based (Cedefop, 2014; Georgiadis, 2014). We envisage unemployment scarring to be strongest in contexts where employers expect smooth school-to-work transitions. This is most likely the case for holders of IVET certificates, especially if those certificates signal an occupation-specific apprenticeship training. We therefore expect to find the strongest unemployment scarring difference between applicants with different types of education - to the disadvantage of IVET certificate holders - in Switzerland and to a lesser extent in Norway. In Greece and Bulgaria, in contrast, we do not expect unemployment scarring to vary across different types of education.

Table 5.1 summarizes the assumed relationships between macro contexts and unemployment scarring for each country. Given that there are just four countries in our study, our attempts to identify relevant 
Table 5.1 Assumed relationships between country contexts and unemployment scarring

\begin{tabular}{|c|c|c|c|c|}
\hline & Bulgaria & Greece & Norway & Switzerland \\
\hline $\begin{array}{l}\text { Economic } \\
\text { context: youth } \\
\text { unemployment } \\
\text { rate }\end{array}$ & Moderate & High & Low & Low \\
\hline $\begin{array}{l}\text { Assumed } \\
\text { unemployment } \\
\text { scarring }\end{array}$ & - & - & + & + \\
\hline $\begin{array}{r}\text { Employment } \\
\text { protection } \\
\text { legislation }\end{array}$ & Weak & Tight & Tight & Weak \\
\hline $\begin{array}{l}\text { Assumed } \\
\text { unemployment } \\
\text { scarring }\end{array}$ & - & + & + & - \\
\hline $\begin{array}{c}\text { Education } \\
\text { system }\end{array}$ & $\begin{array}{c}\text { Moderate } \\
\text { IVET share, } \\
\text { school-based } \\
\text { IVET }\end{array}$ & $\begin{array}{c}\text { Low IVET } \\
\text { share, school- } \\
\text { based IVET }\end{array}$ & $\begin{array}{c}\text { Moderate IVET } \\
\text { share, mix of } \\
\text { school- and } \\
\text { company-based } \\
\text { IVET }\end{array}$ & $\begin{array}{l}\text { High IVET } \\
\text { share, dual- } \\
\text { track IVET }\end{array}$ \\
\hline $\begin{array}{l}\text { Assumed } \\
\text { unemployment } \\
\text { scarring }\end{array}$ & - & - & + & ++ \\
\hline
\end{tabular}

Source: Authors' own representation.

factors behind the international differences in unemployment scarring are inevitably tentative. Rather than testing hypotheses in the strict sense through a quantitative comparative country analysis, this chapter presents a theory-driven and explorative multiple case study that is open to further specification in future research.

\section{DATA AND METHODS}

\subsection{Research Design and Sampling}

We carried out a multi-national web survey in which we had embedded a factorial survey experiment, targeting the survey at recruiters who were responsible for filling an advertised job. In contrast to other forms of field 
experiments applied in recruiter studies (e.g., conjoint or audit studies), our factorial survey experiment facilitated the simultaneous variation of multiple applicant features. Based on a pool of hypothetical candidates so-called vignettes - with different combinations of individual characteristics (such as education level and unemployment experience), this method made it possible to measure both the single and joint effects of such signals on how recruiters evaluated the fictional CVs.

We sampled real vacancies in Bulgaria, Greece, Norway and Germanspeaking Switzerland. We use the term real vacancies to refer to open job positions advertised in the four countries from May 2016 to June 2016. We restricted the sampled job advertisements to the five occupational fields of mechanics, finance (banking and insurance), catering (service personnel), nursing and information technology (ICT). This provided us, first, with a sample of low-, middle- and high-skilled jobs; second, with both gendermixed and gender-typed jobs; third, with occupations that are more or less dependent on and linked to technological innovations; and, finally, with jobs with higher and lower turnover rates (for further details, see Hyggen et al., 2016).

To ensure a sufficient match between the requirements of the selected vacancies and the characteristics of the hypothetical job candidates in the vignettes, we applied internationally comparable sampling criteria for each occupational field. By restricting the sampling of job advertisements to a narrow selection of detailed ISCO codes (International Standard Classification of Occupations), we ensured a reasonable fit between the real job profiles and the standardized vignettes designed for each occupational field. Hyggen et al. (2016) have described our detailed sampling strategies, including the choice of job-advertising communication channels, the exact procedures whereby recruiters were contacted and national-specific adaptions of the standardized sampling strategy.

The global response rate was 16 per cent (completed survey). The response rate was highest in Switzerland at 27 per cent and lowest in Greece at 10 per cent (Bulgaria: 17 per cent; Norway: 14 per cent). All cases with complete data on the research variables were included in the analytical sample for this chapter. This resulted in a final sample of 2885 recruiters and $27612 \mathrm{CVs}$.

\subsection{Variables}

The experimental variables include:

1. Combinations of occupational specificity of education and level of education and work experience (nine categories); 
2. Different combinations of duration and timing of unemployment (seven categories);

3. Gender (two categories); and

4. A national variable that makes it possible to capture country-specific recruitment issues (two categories).

These criteria resulted in a universe of 252 vignettes, that is possible combinations of signals (see the description of the experimental variables in Table 5A.1, Appendix, this chapter). Based on pretest response rates, we decided to field optimized subsets of 164 vignettes in Norway and Switzerland and subsets of 92 vignettes in Bulgaria and Greece (for further details of the experimental design, see Hyggen et al., 2016).

The variable occupational specificity of education and work experience reflects whether the applicant had participated in training and had worked in the occupational field of the advertised job or in an unrelated occupational field. This variable has three categories:

1. Occupation-specific education and work experience;

2. Non-occupation-specific education and work experience; and

3. Occupation-specific education but work experience in deskilling jobs.

Deskilling jobs refers to work experience in jobs for which the employee is overqualified and where previously acquired qualifications are no longer used and further trained; a typical deskilling job is call-centre agent. The $\mathrm{CVs}$ of the respective hypothetical candidates would thus show up to five years of work experience in a call centre. Given three different levels of education and work experience (low, middle, high), this resulted in nine possible combinations of education and work experience.

Our research design allowed for disentangling duration and timing of unemployment. In this chapter, however, we dichotomize this variable (unemployment vs no unemployment) for ease of presentation and interpretation. We further include applicants' gender in the analysis. Both nationality and the total time span of five years of labour market experience (employed or unemployed) since leaving formal education are held constant.

We asked employers to rate ten fictitious CVs with regard to the position for which they were recruiting at the time of sampling (in Greece, each recruiter assessed eight vignettes). The statement read: 'What are the chances that a candidate with the $\mathrm{CV}$ shown above would be considered for the advertised job?' Employers responded using a rating scale ranging from 0 'practically zero' to 10 'excellent'. 


\subsection{Analytical Strategy}

Given that each recruiter rated multiple vignettes, we cannot treat their assessments as independent measures. Unobserved characteristics (such as current mood) may have affected a recruiter's ratings. We therefore employed random-effects multi-level linear regression models (see Auspurg and Hinz, 2015) to examine the effects of unemployment spells on the ratings. To enable interpretation of the ratings, we calculated the marginal effects (and their confidence intervals) of our research variables unemployment and having worked in deskilling jobs. To test our hypothesis on the scarring effects of the two variables, we estimated country-specific regression models (for detailed model specifications, please refer to Imdorf et al., 2017).

To interpret the following graphs, we also relied on several postestimation significance tests of the differences between countries and education levels. The reported marginal effects refer to hypothetical job candidates who fulfil all the requirements of the advertised job regarding educational qualifications (level as well as occupational field of study) and job experience. We calculated the marginal effects by holding constant the match between the candidate and the job as regards the required education level and the occupational specificity, while averaging the other variables at their means.

\section{UNEMPLOYMENT SCARRING ACROSS COUNTRIES AND EDUCATION LEVELS}

\subsection{Unemployment Scarring Across Countries}

In line with our assumption, Figure 5.1 shows that unemployment scarring was stronger in Switzerland and Norway where youth unemployment rates were lower. The scarring effects of unemployment differed significantly between countries, with the strongest scarring by far being found in Norway (reduced rating of -1.1 points), followed by Switzerland (-0.7 points) (see Table 5A.2 in the Appendix, this chapter). The negative effects of unemployment in Bulgaria and Greece were smaller and not significant. The differences in recruiters' evaluations of unemployment were significant between Norway and all other countries, whereas Switzerland differed from Greece at a significance level only of $p=0.10$ and did not differ from Bulgaria. The results for the Bulgarian and Greek respondents did not differ significantly.

At least as far as employer-induced scarring effects are concerned, 


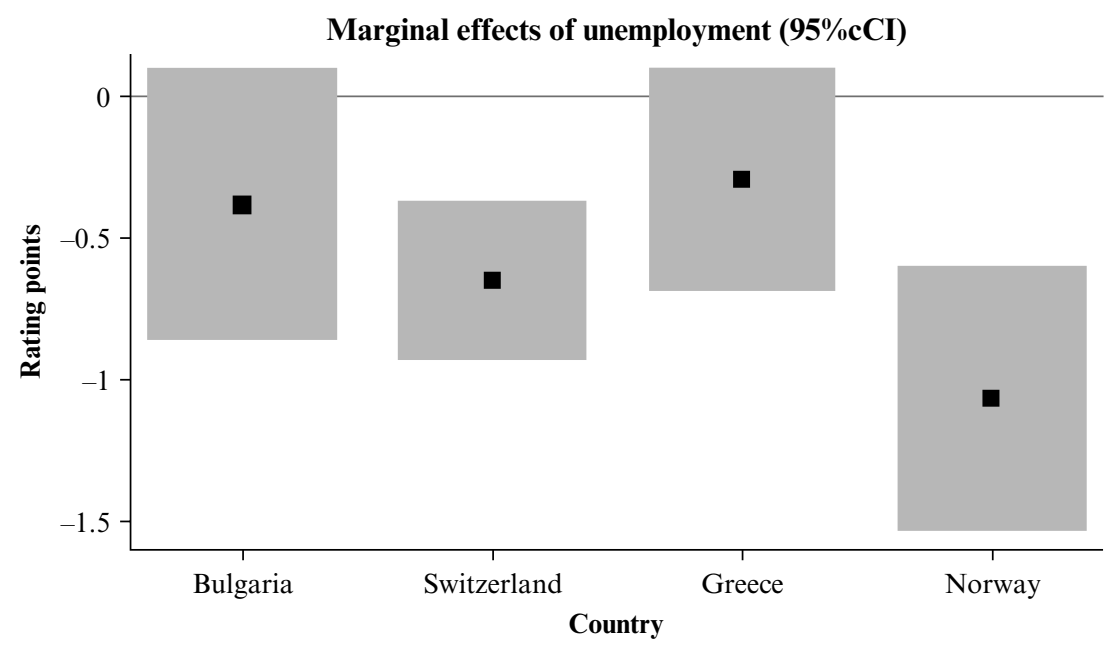

Source: Original data from authors.

Figure 5.1 Scarring effects (incl. 95\% confidence intervals) of unemployment on recruiters' ratings across four countries

our findings suggest that one should be cautious not to overstate unemployment scarring in countries that are especially affected by youth unemployment.

The difference between the two economically well-performing countries - a stronger detrimental effect of unemployment in Norway than in Switzerland - supports our second assumption: the stricter EPL in Norway compared to Switzerland may play a determining role in recruiters' decisions whether to employ applicants who have experienced early job insecurity. However, we could not find a comparable difference between Greece (high protection) and Bulgaria (low protection). An explanation might be that national economic performance has more explanatory power concerning unemployment-induced scarring and that - below a certain level - economic performance overshadows the effect of employment protection. In addition, Greece has recently been subject to profound reforms as part of fiscal-discipline policies imposed by the structural adjustment programmes accompanying the Memoranda of Understanding between this country and its creditors. According to this document, Greek labour market reforms should aim at expanding flexible forms of employment (as against steady and full-time employment) and flexible working hours, at facilitating layoffs and at changing how collective bargaining determines wages (Kouzis, 2014; for additional information, see Karamessini et al., 2016). 


\subsection{Unemployment Scarring for Different Educational Groups}

When testing for education-specific effects on unemployment scarring, we found evidence only for some of the countries in our sample (see Figure 5.2; also see Table 5A.2 in the Appendix, this chapter). In Switzerland, holders of upper-secondary school diplomas with vocational training experienced the strongest (-1.1) unemployment scarring, while holders of tertiary degrees experienced the weakest (insignificant) scarring (for an in-depth analysis of the Swiss case, see Shi et al., 2018). In Greece and Norway we observed a weak and insignificant tendency towards stronger scarring amongst upper-secondary school graduates, whereas in Bulgaria, lower-secondary school graduates seemed to experience the strongest scarring effects. Again, differentiating between different durations and timings of unemployment may lead to results that diverge from the current findings.

The evident unemployment scarring found for holders of vocational diplomas in Switzerland is in line with our assumptions. Di Prete et al. (2017) have argued that vocational graduates in countries with a pronounced dual-track IVET system enjoy high employability because employers trust IVET credentials, enabling, so one would expect, vocational graduates to transition smoothly into the labour market. Unemployment spells are outside the general norm and are therefore penalized by employers. But we did not observe the same kind of negative effect in Norway. As expected in Bulgaria and Greece, which both lack a company-based IVET system, we did not find significant differences between education levels. We thus found only partial support for our assumption that unemployment scarring is particularly strong for holders of vocational diplomas in countries where IVET is an important sector of upper-secondary education and where it is organized in a dual-track system. We might explain the weaker and insignificant effect in Norway compared to Switzerland with the less pronounced focus on dual-track vocational education in favour of a combination of school-based vocational education and company-based learning on the job.

Our results encourage further investigations into the long-term consequences of IVET in countries with strong dual-track IVET systems. We assume that recruiters do not expect to find interrupted career paths for holders of IVET diplomas because their overall job-finding rate is high, so that recruiters might interpret such occurrences as a sign of problematic traits in the job applicant. However, although vocational graduates have traditionally enjoyed smooth transitions from school to work, they increasingly face competition from more experienced job applicants because of the growing complexity in work content and expanding job 


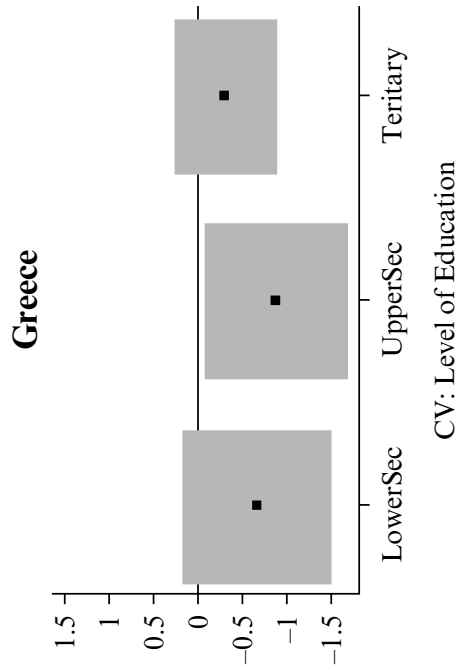

słu!̣od sิu!̣ey

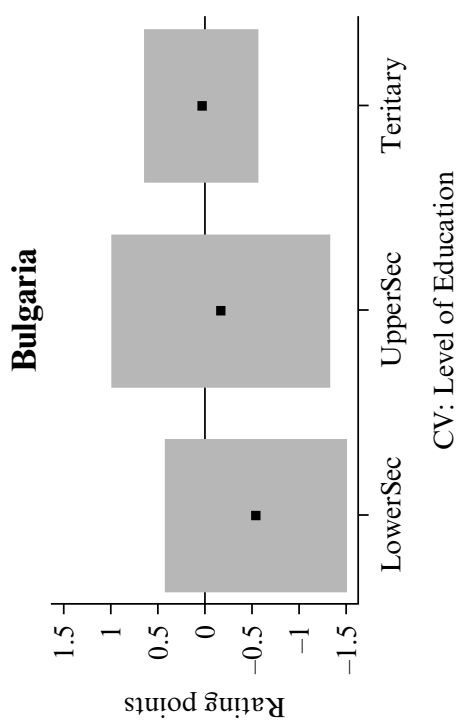

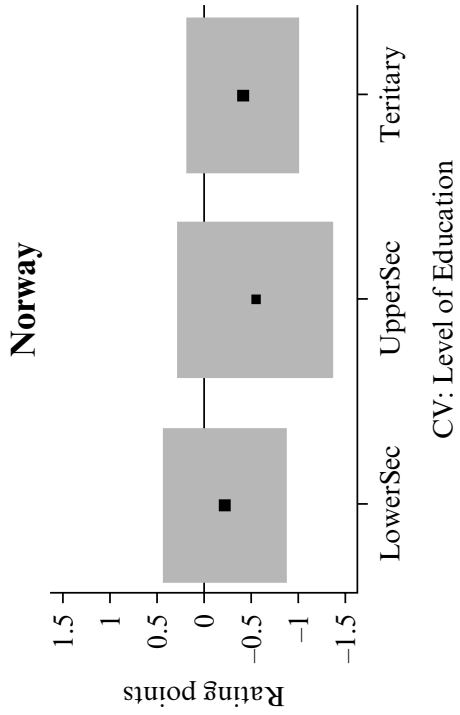

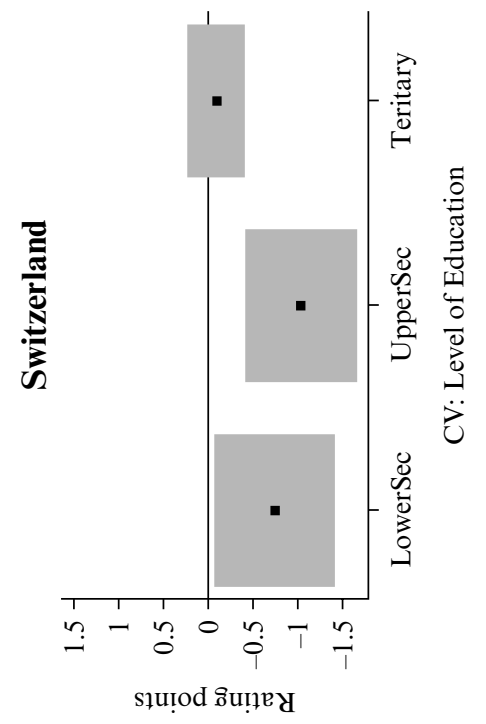

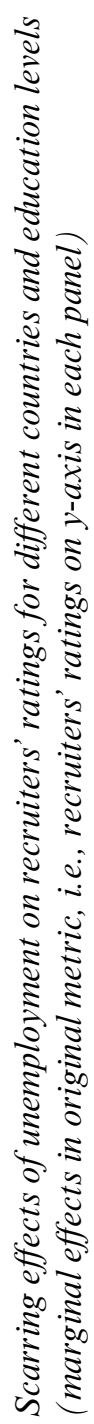

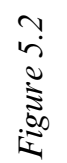


requirements, as Salvisberg and Sacchi (2014) have shown for Switzerland. If the recruiter's perception and expectations do not adapt to these structural changes, holders of vocational diplomas with limited or insecure job experience may face increasing employment difficulties. Moreover, one might assume that the occupation-specific or even firm-specific skills gained during IVET could deteriorate faster than the more general skills acquired in tertiary education. Hence, unemployment spells might be particularly detrimental for holders of IVET qualifications.

We also checked for gender-specific differences in unemployment scarring. Our preliminary results showed that male and female applicants were penalized to similar extents for unemployment spells in every country in our sample. However, we suspect that gender-specific scarring may appear if one differentiates between occupational fields and job types that are more or less gender typical.

\section{BEYOND UNEMPLOYMENT: FURTHER FACETS OF JOB INSECURITY}

Job insecurity has different facets and it can also result in detrimental forms of employment in a person's future occupational career. For instance, when it is difficult to find employment, people may take jobs for which they are overqualified just so that they can earn income. Especially in countries with few vacancies and fierce competition between applicants, one can expect to find a larger share of people working in jobs for which they are overqualified. Such work experience can function either as a 'stepping stone' to better jobs in the future or as a 'dead end' (Pedulla, 2016). Furthermore, one can regard certain types of jobs as insecure jobs. For instance, temporary jobs with fixed contracts provide less security than permanent jobs (Scarpetta et al., 2012). In the following we are interested in how employers perceive such previous employment experiences when hiring for qualified vacancies.

\subsection{Deskilling Jobs}

As with unemployment scarring, work experience in jobs for which one is overqualified and where previously acquired qualifications are no longer used and further trained ('bad jobs') is likely to contribute to deteriorating skills. In line with human capital theory, deskilling jobs can negatively influence one's future chances of finding a position that matches one's educational attainment and skill level. Signalling theory suggests that employers may interpret a deskilling job experience in one 
of two ways. On the one hand, employers can see it as signalling the applicant's inability to find matching jobs or as indicating low motivation or low productivity (Karren and Sherman, 2012; Nunley et al., 2016). On the other hand, employers might understand deskilling job experiences as evidence of strong commitment to work and high motivation (Athey and Hautaluoma, 1994). Similar to employers' assessment of periods of unemployment, we can expect their view on deskilling job experiences to largely depend on contextual factors.

Our methodological design allowed us to measure recruiters' evaluations of work experience in deskilling jobs, which we represented as working as a call-centre agent for five years. By applying the same analytical strategies used in studying unemployment, we found that the negative effect of deskilling job experience on recruiters' ratings was stronger than the unemployment effect in all four countries. Our findings are thus in line with previous studies that have demonstrated the detrimental effect of deskilling job experience and have given less support to its positive effect on future employment chances. These results favour the explanation that employers interpret long periods of call-centre work as periods where previously acquired skills are no longer used, rather deteriorate, or as evidence of a job candidate's lack of interest in his/her learned occupation. We found no differences between genders in this regard.

We found the strongest penalization in employers' ratings of five-yearlong call-centre work in Norway (-3.4 points) and Bulgaria (-3.3 points), whereas the rating reductions in Greece and Switzerland amounted to substantially less (-2.2 points and -2.4 points, respectively; see Table 5A.3 in the Appendix, this chapter). The differences between Norway and Bulgaria as well as those between Greece and Switzerland were not significant. This pattern differs from the unemployment effects, where we observed stronger scarring in Norway and Switzerland. However, without more qualitative information a statistical comparison between countries of scarring effects from deskilling job experiences contributes little added value at this point. Furthermore, working as a call-centre agent may have a different status in each of the four countries. Depending on the job requirements (call centres that provide information services and helplines versus call centres aiming to sell merchandise and services), salary and sector (public versus private), working as a call-centre agent may be considered to be a higher or lower qualified job in different country contexts, and it may thus not necessarily be regarded as a deskilling job. How recruiters perceive call-centre work experience could depend on the overall job market situation, such as the labour market tightness in the specific occupational field and country. Moreover, the duration of having worked for five years in a call centre may be more plausible in some countries than in others. Hence, further 
research is needed to consider variations of the 'call-centre effect' between occupational fields within and between countries in order to explain the observed country differences.

Likewise, we should take the stronger negative effect of having worked in a call centre compared to having previous or ongoing unemployment - a result found in all four countries - with a grain of salt. Our research design set the maximum length of unemployment spells in the fictitious CVs at 20 months, whereas the work in deskilling jobs lasted five years. Nonetheless (and this is probably the most important lesson from this study), our findings clearly demonstrate that precarious work in deskilling jobs for a longer period of time has a detrimental impact on future chances of finding a job - irrespective of country.

\subsection{Job-Hopping}

Finally, job insecurity can be related to instability and uncertainty in employment conditions. Flexibility in the labour market often goes hand in hand with temporary employment contracts, which offer less stability than permanent contracts. Short-term contracts can lead to increased numbers of jobs or, in other words, to job-hopping. Frequent job changes may, in turn, affect future employment chances because employers may take job-hopping as a negative signal.

In order to study whether employers object to job-hopping, we included a question in the online survey asking: 'Would you have reservations about hiring a person who has been changing jobs frequently?' To be able to compare employers' perceptions about applicants' job-hopping and applicants' unemployment, we included another survey item: 'Would you have reservations about hiring a person who has been unemployed during the last two years?'

Figure 5.3 shows that employers clearly evaluated job-hopping more negatively than unemployment in all four countries. The share of respondents who had no reservations about hiring jobseekers who had been unemployed for the last two years was larger than the share of respondents who had no reservations about hiring applicants with frequent job changes. Similarly, the proportion of respondents who had reservations about hiring applicants with a history of job-hopping was considerably larger than the proportion of respondents who had reservations about hiring applicants with a history of unemployment. In further interpreting the results, one should keep in mind that social desirability might have driven some of these responses.

The descriptive statistics for the job-hopping item show that the share of employers with reservations about hiring applicants with job-hopping 
Reservations against hiring the unemployed

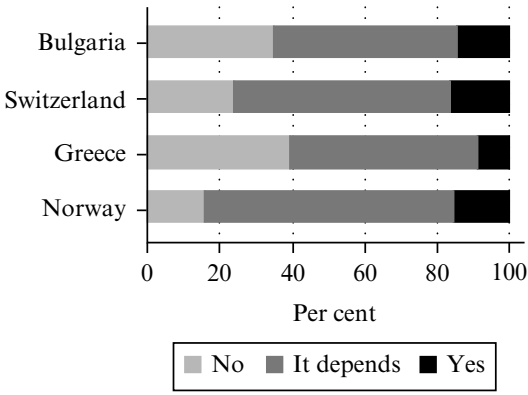

Reservations against hiring job-hoppers

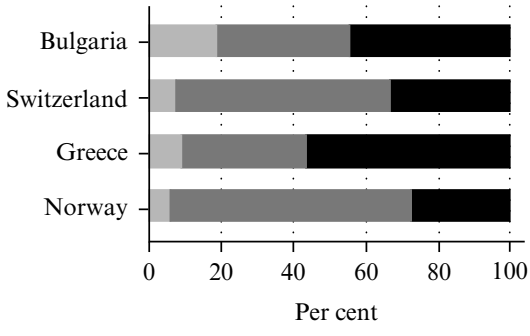

No $\square$ It depends $\mathbf{a}$ Yes

Source: Original data from authors.

\section{Figure 5.3 Employers' assessments of unemployment and job-hopping compared}

behaviour was larger in Greece and Bulgaria than in Switzerland and Norway. This is the opposite pattern than for the evaluation of hiring longterm unemployed applicants, where the proportion of employers expressing reservations tended to be larger in Norway and Switzerland than in Bulgaria and, especially, in Greece (also see Section 5.1). It may be that in countries where the signal value of unemployment is generally weaker due to high shares of (youth) unemployment, recruiters pay more attention to other forms of job insecurity, such as job-hopping, which they may consider a more relevant signal in these national contexts. Our findings at least do not support the counterargument that in countries where job stability is low, jobhopping may serve less as a signal for recruiters than in countries with lower labour market volatility. Indeed, Ayllón and Ramos (2017) have found that levels of labour market volatility, which they measured in terms of changes in wages and transitions into and out of employment, are higher in Bulgaria and Greece than in Norway (the Swiss case was not included in their study). It is therefore reasonable to assume that, whereas unemployment can occur through no fault of one's own in contexts with high unemployment (and is therefore of little information value for recruiters), job-hopping is less likely to be interpreted as a consequence of the overall economic situation or as beyond the applicant's control. Employers may rather more often view job-hopping as a negative signal. To sum up, our results showing the detrimental effects of job-hopping on future employment chances suggest that additional attention should be given to diverse forms of job insecurity, as opposed to only unemployment. 


\section{SUMMARY AND CONCLUSION}

In this study we analysed three contextual factors that are likely to determine how recruiters evaluate various signals of job insecurity in young job applicants' trajectories: the labour market conditions, measured by the share of young people who are unemployed in a country; the strictness of the country's EPL; and the design of the country's education system. We presented hypothetical CVs with different educational and occupational trajectories to real recruiters. The recruiters were then asked to rate these fictitious candidates on their chances of being considered for an advertised vacancy they were recruiting for at the time.

Our results suggest, first, that country differences in unemployment scarring are associated with different youth unemployment rates. In Norway and Switzerland, where youth unemployment was lowest, we found pronounced scarring effects from having been unemployed in the initial years of one's career, while no such effects were evident in Bulgaria and Greece, where youth unemployment was much more prevalent. Second, stronger employment protection might contribute to more pronounced unemployment scarring when national unemployment rates are taken into account. In addition, we found variations in unemployment scarring for different groups of educational attainment in Switzerland. In this country the system of upper-secondary education is strongly dominated by IVET, and IVET is mainly company based and dual track. Although it is commonly assumed that a dual-track IVET system enhances smooth school-to-work transitions for its graduates and reduces youth unemployment, our study shows that IVET graduates experience the strongest unemployment scarring in Switzerland. Our findings thus contribute to understanding unemployment scarring in relation to country-specific settings. We believe future research should take greater account of local and organizational contexts of scarring, such as the role of geographical location, firm size or the wage for the advertised position.

Another contribution of our study on scarring is that it draws attention to the diversity of job insecurity. An exclusive focus on unemployment is not sufficient for fully understanding how early job insecurity and 'bad jobs' affect labour market outcomes. We have shown that employers negatively evaluate job-hopping and work experience in deskilling jobs when assessing applicants. The detrimental impact of such experiences may be just as relevant as the effect of having a history of unemployment. In other words, there is a need for a more nuanced perception of what factors may have the most negative effects on young people's future labour market outcomes. For instance, having worked in deskilling jobs for a lengthy period may decrease future employment chances in skilled jobs more 
strongly than an unemployment spell of up to 20 months. Our analysis shows that in some country contexts employers primarily had reservations about hiring applicants with a history of job-hopping, while they appeared to be less concerned about hiring applicants who had been unemployed.

These insights are relevant for discussions concerning passive and active labour market policies. Seeking to return skilled unemployed young people as quickly as possible to the labour market may compromise their long-term job prospects. In this light, national public employment services should carefully assess the appropriateness of their measures in individual cases. Because both deskilling jobs and job-hopping can have detrimental effects on a young worker's professional career, pushing the unemployed into the labour market at any price may not be a good strategy if it happens at the cost of job quality. Future employers may not see previous work in deskilling jobs as any better than having a history of unemployment, indeed quite the opposite. Likewise, taking up a series of temporary jobs may not be a promising career-building strategy for young workers. Jobhopping may easily have negative consequences for one's future chances of finding a skilled job. But the social and institutional contexts in which such scarring effects evolve are not yet very clear. More thorough research is needed on the effects of job-hopping and deskilling work experience in different economic and institutional contexts.

Finally, further analyses are desirable that take account of interaction effects between the characteristics of jobseekers and work organizations. Future research should investigate whether and how intersections between country- and firm-level contexts, individual characteristics like gender or ethnicity, and individual adjustments such as job-hopping impact on the risk of scarring. The analysis of gender differences in the risk of scarring needs to be sensitive towards gender-segregated occupational fields that are more or less inclusive for women and/or men.

\section{REFERENCES}

Allmendinger J (1989) Educational systems and labor market outcomes. European Sociological Review 5(3): 231-50.

Allmendinger $\mathbf{J}$ and Leibfried S (2003) Education and the welfare state: The four worlds of competence production. Journal of European Social Policy 13(1): 63-81.

Athey TR and Hautaluoma JE (1994) Effects of applicant overeducation, job status, and job gender stereotype on employment decisions. The Journal of Social Psychology 134(4): 439-52.

Atkinson J, Lesley G and Meager N (1996) Employers, recruitment and the unemployed. IES Report no. 325. Brighton, UK: Institute for Employment Studies.

Auspurg K and Hinz T (2015) Factorial Survey Experiments. London, UK: Sage. 
Ayllón S and Ramos X (2017) Youth earnings and labour market volatility in Europe. International Labour Review. Epub ahead of print 13 November 2017. DOI: 10.1111/ilr.12069.

Bäckman O, Jakobsen V, Lorentzen T, Österbacka E and Dahl E (2011) Dropping out in Scandinavia. Social exclusion and labour market attachment among upper secondary school dropouts in Denmark, Finland, Norway and Sweden. IFFS Working Paper no. 8. Stockholm: Institute for Futures Studies.

Biewen M and Steffes S (2010) Unemployment persistence. Is there evidence for stigma effects? Economics Letters 106(3): 188-90.

Bills DB (2003) Credentials, signals, and screens: Explaining the relationship between schooling and job assignment. Review of Educational Research 73(4): 441-69.

Bjerkeng H (2015) Feasibility study of the introduction of the Hamburg Model into Norwegian vocational education system. http:/www.vet-bsr.eu/wp-content/ uploads/2015/09/Feasibility-study-2015-Norway.pdf (accessed 15 April 2017).

Bonoli G (2014) Employers' attitudes towards long-term unemployed people and the role of activation in Switzerland. International Journal of Social Welfare 23(4): 421-30.

Breen R (2005) Explaining cross-national variation in youth unemployment. Market and institutional factors. European Sociological Review 21(2): 125-34.

Brown S and Taylor K (2009) Reservation wages, expected wages and the duration of unemployment. Evidence from British panel data. IZA Discussion Paper no. 3981. Bonn: Institute for the Study of Labor.

Buchmann M and Sacchi S (1998) The transition from school to work in Switzerland. Do characteristics of the educational system and class barriers matter? In: Shavit Y and Müller W (eds) From School to Work. A Comparative Study of Educational Qualifications and Occupational Destinations. Oxford, UK: Clarendon Press, pp. 407-42.

Cedefop (2014) Vocational Education and Training in Greece. Short Description. Luxembourg: Publications Office of the European Union.

Devins D and Hogarth T (2005) Employing the unemployed: Some case study evidence on the role and practice of employers. Urban Studies 42(2): 245-56.

Dietrich H (2012) Youth unemployment in Europe. Theoretical considerations and empirical findings. International Policy Analysis Report. Bonn: Friedrich-Ebert-Stiftung.

Di Prete TA, Eller CC, Bol T and Van de Werfhorst HG (2017) School-to-work linkages in the United States, Germany, and France. American Journal of Sociology 122(6): 1869-938.

Eriksson S and Rooth D-O (2014) Do employers use unemployment as a sorting criterion when hiring. Evidence from a field experiment. American Economic Review 104(3): 1014-39.

Eurostat (2014) Share of students in vocational programmes. https://ec.europa.eu/ eurostat/statistics-explained/index.php/File:Share_of_students_in_vocational_pr ogrammes,_2014(\%25).png (accessed 6 September 2017).

Eurostat (2015) Share of young people neither in employment nor in education and training, by sex and age, 2015. http://ec.europa.eu/eurostat/statistics-explained/ index.php/File:Share_of_young_people_neither_in_employment_nor_in_educa tion_and_training,_by_sex_and_age,_2015\%25.png (accessed 23 April 2017).

Gangl M (2003a) The only way is up? Employment protection and job mobility among recent entrants to European labour markets. In: Kogan I and Müller W 
(eds) School-to-Work Transitions in Europe: Analyses of the EU LFS $2000 \mathrm{Ad}$ Hoc Module. Mannheim: MZES, pp. 121-50.

Gangl M (2003b) Explaining change in early career outcomes: Labour market conditions, educational expansion, and youth cohort sizes. In: Müller W and Gangl M (eds) Transitions from Education to Work in Europe. Oxford, UK: Oxford University Press, pp. 251-76.

Georgiadis N (2014) From school to work - How are vocational education, training and employment related? Perspective Report. Athens: Friedrich-Ebert-Stiftung.

Heritage Foundation (2017) Index of economic freedom. http://www.heritage.org/ index/explore?view=by-region-country-year (accessed 6 September 2017).

Hora O, Horáková M and Sirovátka T (2016) Institutional determinants of early job insecurity in nine European countries. NEGOTIATE Working Paper no. 3.4. www.negotiate-research.eu/files/2015/04/NEGOTIATE-working-paper-D3.4.pdf (accessed 27 April 2017).

Hyggen C, Imdorf C, Parsanoglou D, Sacchi S, Samuel R, Stoilova R, Shi LP, Yfanti A and Yordanova G (2016) Understanding unemployment scars: A vignette experiment of employers' decisions in Bulgaria, Greece, Norway and Switzerland. NEGOTIATE Working Paper no. 7.2. www.negotiate-research.eu/files/2015/04/ NEGOTIATE-working-papers-no-D7.2.pdf (accessed 2 April 2018).

ILO (2015) Employment Protection Legislation: Summary Indicators in the Area of Terminating Regular Contracts (Individual Dismissals). Geneva: International Labour Organization.

Imbens GW and Lynch LM (2006) Re-employment probabilities over the business cycle. Portuguese Economic Journal 5(2): 111-34.

Imdorf C, Shi LP, Sacchi S, Samuel R, Hyggen C, Stoilova R, Yordanova G, Boyadjieva P, Ilieva-Trichkova P, Parsanoglou D and Yfanti A (2017) Explaining employers' hiring decisions: A comparative study of employers' risk assessment. NEGOTIATE Working Paper no. 7.3. https://negotiate-research.eu/files/2015/04/ NEGOTIATE_working_paper_D7.3.pdf(accessed 2 April 2017).

Karamessini M, Kominou K and Papazachariou A (2016) Institutional determinants of early job insecurity in nine European countries. National Report Greece for NEGOTIATE Working Paper no. 3.4. See https://negotiate-research.eu/ files/2018/07/WP-3.4_National_Report-Greece.pdf (accessed 28 April 2018).

Karren R and Sherman K (2012) Layoffs and unemployment discrimination: A new stigma. Journal of Managerial Psychology 27(8): 848-63.

Kouzis I (2014) Labour in the vortex of economic crisis and memoranda. In: Kiousis I and Zamparloukou S (eds) Dimensions of the Current Crisis: Society and Crisis. Athens: Pedio Publications, pp. 231-46.

Lupi C and Ordine P (2002) Unemployment scarring in high unemployment regions. Economics Bulletin 10(2): 1-8.

Ma CA and Weiss AM (1993) A signaling theory of unemployment. European Economic Review 37(1): 135-57.

Mooi-Reci I and Ganzeboom HB (2015) Unemployment scarring by gender: Human capital depreciation or stigmatizing? Longitudinal evidence from the Netherlands, 1980-2000. Social Science Research 52: 642-58.

Nunley MJ, Pugh A, Romero N and Seals RA (2016) The effects of unemployment and underemployment on employment opportunities: Results from a correspondence audit of the labor market for college graduates. Industrial and Labour Relations Review 70(3): 642-69. 
Pedulla DS (2016) Penalized or protected? Gender and the consequences of nonstandard and mismatched employment histories. American Sociological Review 81(2): 262-89.

Pissarides CA (1992) Loss of skill during unemployment and the persistence of employment shocks. The Quarterly Journal of Economics 107(4): 1371-91.

Pissarides CA (2000) Equilibrium Unemployment Theory. 2nd ed. Cambridge, MA: MIT Press.

Sacchi S, Kriesi I and Buchmann M (2016) Occupational mobility chains and the role of job opportunities for upward, lateral and downward mobility in Switzerland. Research in Social Stratification and Mobility 44: 10-21.

Salvisberg A and Sacchi S (2014) Labour market prospects of Swiss career entrants after completion of vocational education and training. European Societies 16(2): 255-74.

Scarpetta S, Livanos I, Núñez I, Riddell WC, Song X and Sonnet A (2012) Challenges facing European labour markets: Is a skill upgrade the appropriate instrument? Intereconomics 47(1): 4-30.

Scarpetta S, Sonnet A and Manfredi T (2010) Rising youth unemployment during the crisis: How to prevent negative long-term consequences on a generation? OECD Social, Employment and Migration Working Paper no. 106. Paris: OECD.

SERI (2015) Vocational and professional education and training in Switzerland: Facts and figures 2015. Berne: State Secretariat for Education, Research and Innovation.

Shi LP, Imdorf C, Samuel R and Sacchi S (2018) How unemployment scarring affects skilled young workers: Evidence from a factorial survey of Swiss recruiters. Journal of Labour Market Research 52(7): DOI: https://doi.org/10.1186/ s12651-018-0239-7.

Spence M (1973) Job market signaling. The Quarterly Journal of Economics 87(3): 355-74.

Van der Velden R and Wolbers M (2001) The integration of young people into the labour market within the European Union: The role of institutional settings. TSER/ROA Working Paper no. 7E. Maastricht: Research Centre for Education and the Labour Market.

Van der Velden R and Wolbers M (2003) The integration of young people into the labour market: The role of training systems and labour market regulation. In: Müller W and Gangl M (eds) Transition from Education to Work in Europe: The Integration of Youth into EU Labour Markets. Oxford, UK: Oxford University Press, pp. 186-211.

Walther A (2006) Regimes of youth transitions: Choice, flexibility and security in young people's experiences across different European contexts. Young 14(2): 119-39. 


\section{APPENDIX}

\section{Table 5 A.1 Description of experimental variables and their levels}

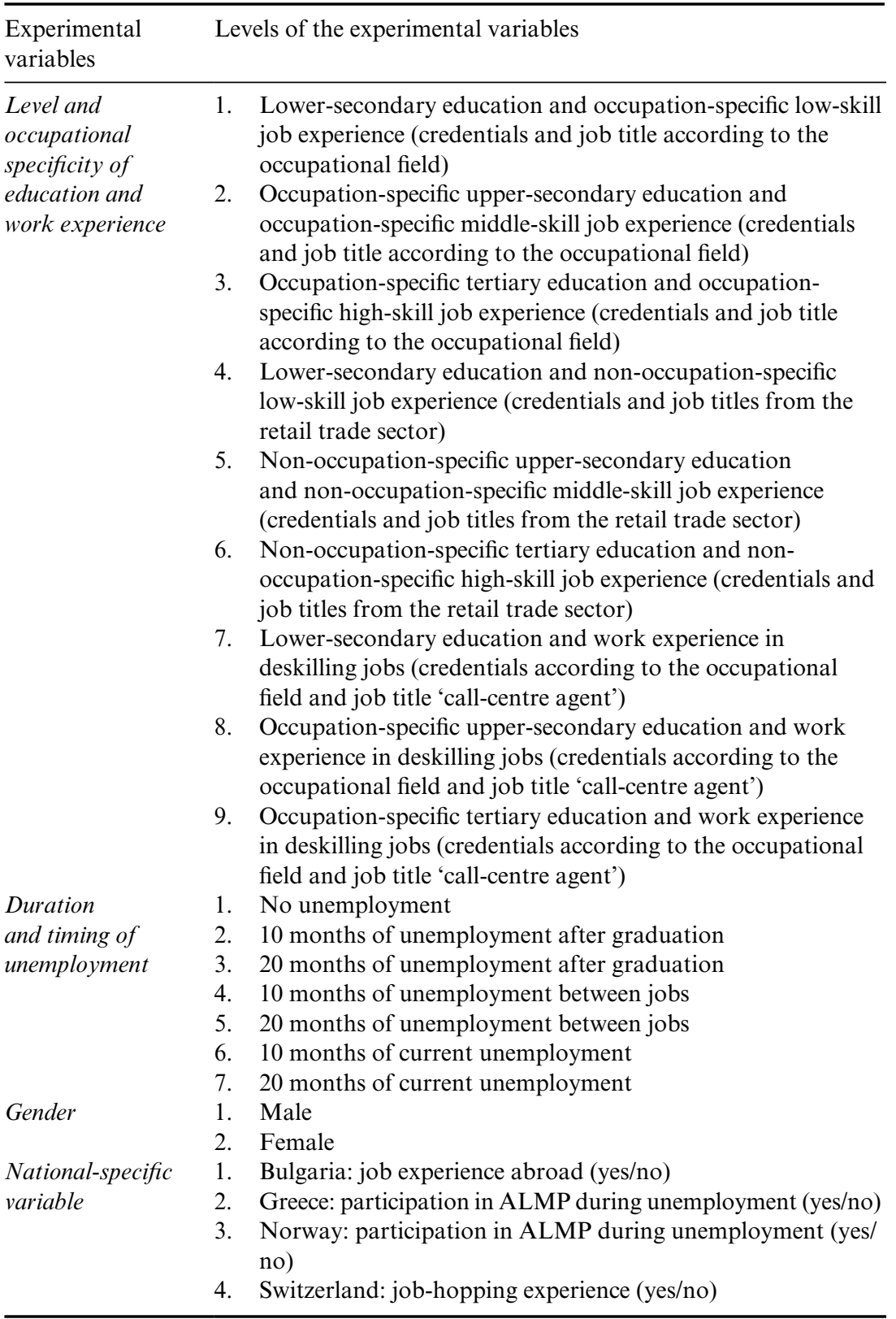


Table 5A.2 Marginal effects of unemployment

\begin{tabular}{lcccc}
\hline & Greece & Bulgaria & Switzerland & Norway \\
\hline Overall & -0.29 & -0.38 & $-0.65^{* * *}$ & $-1.07^{* * *}$ \\
& $(0.20)$ & $(0.24)$ & $(0.14)$ & $(0.24)$
\end{tabular}

By education level

$\begin{array}{lcccc}\text { Lower- } & -0.67 & -0.56 & -0.76^{*} & -0.21 \\ \text { secondary } & (0.43) & (0.50) & (0.34) & (0.34) \\ \text { Upper- } & -0.88^{*} & -0.18 & -1.05^{* * *} & -0.54 \\ \text { secondary } & (0.42) & (0.59) & (0.32) & (0.42) \\ \text { Tertiary } & -0.31 & 0.01 & -0.11 & -0.42 \\ & (0.29) & (0.31) & (0.17) & (0.30)\end{array}$

By occupational field

\begin{tabular}{lcccc} 
Mechanics & -0.54 & -0.35 & -0.28 & -0.06 \\
& $(0.34)$ & $(0.38)$ & $(0.21)$ & $(0.32)$ \\
Finance & $-0.83+$ & $0.61+$ & -0.30 & -0.14 \\
& $(0.47)$ & $(0.34)$ & $(0.28)$ & $(0.26)$ \\
Nursing & -0.60 & $-1.07^{*}$ & $-0.74^{* *}$ & -0.25 \\
& $(0.41)$ & $(0.44)$ & $(0.26)$ & $(0.27)$ \\
Catering & $-0.82^{*}$ & 0.38 & $-0.80^{*}$ & -0.78 \\
& $(0.35)$ & $(0.79)$ & $(0.36)$ & $(0.76)$ \\
ICT & -0.43 & $-0.79+$ & $-0.96^{* * *}$ & $-0.90^{*}$ \\
& $(0.38)$ & $(0.47)$ & $(0.29)$ & $(0.41)$ \\
\hline
\end{tabular}

Notes: Standard errors in parentheses. Significance levels: + ) $p<0.10 ; *) p<0.05$ **) $p<0.01 ; * * *) p<0.001$.

Source: Original data from authors. 
Table 5A.3 Marginal effects of having worked for several years in a call centre

\begin{tabular}{lcccc}
\hline & Greece & Bulgaria & Switzerland & Norway \\
\hline Overall & $-2.23^{* * *}$ & $-3.27^{* * *}$ & $-2.44^{* * *}$ & $-3.35^{* * *}$ \\
& $(0.23)$ & $(0.27)$ & $(0.17)$ & $(0.27)$ \\
By education level & & & & \\
Lower-secondary & $-1.33^{* * *}$ & $-2.17^{* * *}$ & $-1.32^{* * *}$ & $-0.87^{* * *}$ \\
& $(0.22)$ & $(0.25)$ & $(0.15)$ & $(0.15)$ \\
Upper-secondary & $-1.62^{* * *}$ & $-3.78^{* * *}$ & $-3.25^{* * *}$ & $-1.51^{* * *}$ \\
& $(0.23)$ & $(0.31)$ & $(0.24)$ & $(0.22)$ \\
Tertiary & $-2.37^{* * *}$ & $-2.70^{* * *}$ & $-1.81^{* * *}$ & $-2.65^{* * *}$ \\
& $(0.29)$ & $(0.27)$ & $(0.16)$ & $(0.26)$ \\
\hline
\end{tabular}

Notes: $\quad$ Standard errors in parentheses. Significance levels: +) $\left.p<0.10{ }^{*}\right) p<0.05$; **) $p<0.01 ; * * *) p<0.001$.

Source: Original data from authors. 